\title{
TO BE THE SHADOW* - AWARENESS OF UNDERGRADUATE NURSING STUDENTS: A CASE STUDY
}

\author{
Roberta Waterkemper ${ }^{1}$, Marta Lenise do Prado², José Luis Moya Medina ${ }^{3}$, Kenya Schmidt Reibnitz ${ }^{4}$
}

${ }^{1}$ Ph.D. in Nursing. Adjunct Professor, da Universidade Federal de Ciências da Saúde de Porto Alegre. Porto Alegre, Rio Grande do Sul, Brazil. Email: robswater@ufcspa.edu.br.

${ }^{2}$ Ph.D. in Nursing. Full Professor, Universidade Federal de Santa Catarina (UFSC). Florianópolis, Santa Catarina, Brazil. E-mail: marta.lenise@ufsc.br.

${ }^{3}$ Ph.D. in Philosophy and Educational Sciences. Full Professor, College of Education, Universidad de Barcelona. Barcelona, Spain. E-mail: jlmedina59@gmail.com.

${ }^{4}$ Ph.D. in Nursing. Full Professor, UFSC. Florianópolis, Santa Catarina, Brazil. E-mail: kenya@nfr.ufsc.br.

\begin{abstract}
This was qualitative research in the form of an educational case study. Aimed at understanding the self-consciousness (nursing students) about being a student in a course working with critical pedagogy. It was supported by Freire's liberating theoretical and philosophical education. The study included 14 nursing students. The data were collected through non-participant observation and an open interview script. Data were analyzed using thematic analysis. Three units of thematic analysis were developed: a being without knowledge, a being who absorbs knowledge, and being evaluated by grades. The student is perceived as a being without knowledge, which is absorbed by him through the transmission of content in the classroom by the teacher. Understanding self-consciousness and the world that presents the student is a way to enable the development of his self-consciousness in the world.
\end{abstract}

DESCRIPTORS: Awareness. Students, nursing. Education, higher.

\section{SER A SOMBRA - A CONSCIÊNCIA DE SI DO ACADÊMICO DE ENFERMAGEM: UM ESTUDO DE CASO}

\begin{abstract}
RESUMO: Trata-se de uma pesquisa qualitativa na modalidade de estudo de caso em educação. Objetivou compreender a consciência de si do acadêmico de enfermagem em uma disciplina que trabalha com pedagogia, crítica tendo como suporte teórico-filosófico a educação libertadora de Freire. Participaram deste estudo 14 alunos de enfermagem. Realizou-se a coleta de dados através de observação não participante e um roteiro de entrevista aberta. Os dados foram estudados segundo análise de conteúdo do tipo temática, da qual emergiram três categorias temáticas: "um ser sem conhecimento", "um ser que absorve o conhecimento" e "um ser avaliado por nota". Conclui-se que no início da disciplina o aluno se percebe como um ser sem conhecimento, que o absorve através da transmissão de conteúdos em sala de aula pelo professor. Mesmo diante de uma proposta de ensino menos tradicional e que possibilita ao aluno escolher como irá estudar, observa-se a presença de uma consciência ingênua.
\end{abstract}

DESCRITORES: Conscientização. Estudantes de enfermagem. Educação superior.

\section{SER LA SOMBRA - LA CONCIENCIA DE SÍ DEL ALUMNO DE ENFERMERÍA: UN ESTUDIO DE CASO}

\begin{abstract}
RESUMEN: Se trata de una investigación cualitativa en la forma de un estudio de caso en la educación. Dirigido a entender la conciencia de sí mismo (los estudiantes de enfermería) sobre ser un estudiante en un curso que trabaja con la pedagogía crítica teniendo como apoyo teórico y filosófico la educación liberadora de Freire. Participaron del estudio 14 estudiantes de enfermería. La recogida de los datos ocurrió a través de la observación no participante y un guión de entrevista abierta. Los datos fueron analizados mediante el análisis temático. Se han desarrollado tres unidades de análisis temático: un ser sin conocimiento, un ser que absorbe el conocimiento y un ser evaluado por nota. El estudiante se percibe como un ser sin conocimiento, que es absorbido por él mismo a través de la transmisión de contenidos en el aula por el profesor. Comprender la conciencia de sí mismo y del mundo que presenta el estudiante es una forma de permitir el desarrollo de su conciencia de sí mismo en el mundo.
\end{abstract}

DESCRITORES: Concienciación. Estudiantes de enfermería. Educación superior.

\footnotetext{
"To be the shadow" is an expression used by Paulo Freire in his works to refer to the student who is oppressed, living in the shadow of the oppressor. The oppressed "[...] fear freedom, to the extent that this should be conquered by expelling this shadow, and this would require them to fill the void left by the expulsion, with other content - the autonomy" ${ }^{1: 18}$ 


\section{BACKGROUND}

In education, when it comes to attitude or a student profile, regardless of formal training level, what is seen in the majority of the politicalpedagogical projects for undergraduate nursing courses in Brazil is the achieving of student formation marked by attitudes/critical profile, which should be translated into autonomy, decision making and problem solving abilities, communication skills, interpersonal relationships, among other characterístics. ${ }^{2}$ Many efforts are made by educational institutions to develop teaching and learning processes able to form or mature such attitudes among students. However, in this process, the awareness of the student about him/herself as a human being in training, and the awareness about the world, is forgotten and disregarded, even by scientific studies.

Faced with this context and considering the Educational Project for the Course (EPC) for undergraduates from the Universidade Federal de Santa Catarina (UFSC), the Fundamentals of Professional Nursing Care course implemented a new pedagogical proposal beginning in 2005, supported by critical pedagogy and the adoption of active methodologies. This experiment involved professors and students, who accepted the challenge of changing thoughts, knowledge and attitudes towards their own education. The subject is part of the course curriculum and it is offered in the third semester, concomitantly with Applied Pharmacology and Experiential Learning. It has as its main objective to develop new skills in students about how to learn by stimulating the search for and critical evaluation of data and information through books, periodicals, databases, personal sources of information, and even the experience itself; to perform successive approximations with increasing levels of complexity; and learning by doing, aiming toward the development of psychomotor skills and attitudes throughout the semester, in conjunction with the production of knowledge. All of this is conducted through the process of action-reflection-action, linked to the practice scenarios and search for information in a systematic and related order. The subject is organized during the semester, in three Knowledge Areas (KAs), aimed at the development of its program. These protected areas are developed through multiple teaching strategies, such as: Discussion in Small Groups (DSG), conferences and classes in large group experiences in the hospital practical scenario, socialization, independent studies (activities without the teacher's mediation), simulation in the clinical practice laboratory, and development of a portfolio. The activities are organized based on the Arc of Maguerez, ${ }^{* *}$ and they begin with the student's observation of the reality (experiences and previous knowledge, and experiences in the practice scenario) with the assistance of a professor. This observation occurs in hospital units at different times throughout the semester, and starts on the second day of class. From the observation of reality, students identify learning questions, i.e. questions arising from the curiosity of observing the care scenarios, followed by theoretical studies and application in reality. This makes reference to the act of questioning the context starting from the concrete reality of the subject and creating cognitive conflict - what the student already knows, what he/she does not know, and what he/she needs to learn; it creates a situation in which the student can explain his/her previous knowledge and referencial. ${ }^{3-5}$

This proposal of teaching and learning is challenging for both student and professor, being part of a traditional teaching model that is still hegemonic, where those figures have antagonistic roles, that is, to teach (played by the professor) and to learn (fulfilled by the student), without interaction or integrated participation. So, for the student, to get out of this position of knowledge receiver and take the place of the protagonist of this process is challenging and often daunting.

Thus, it is important to understand how the student, while starting this subject, perceived himself/herself, as well as the knowledge about his/ her perception of the teaching-learning process as experienced in previous semesters until this moment. This perception can help in the identification of the self-awareness and the awareness of the world, as stated by Paulo Freire. Self-awareness and the awareness of the world, according to this author, are the main factors that allow students to achieve a critical attitude, because they result in the effort to know the obstacles, i.e. the extreme situation, their reasons for being and their reasons for their own existence. A student, by being aware

\footnotetext{
* The Arch of Maguerez is a teaching strategy, developed in five stages: observation of reality, learning questions, theorizing, solution hypotheses, and application in reality. This method assumes that learning starts from the very observation of reality ${ }^{3}$
} 
of himself/herself and of the world is able to realize his/her unfinished condition and the need to evolve. Therefore, development of awareness is a process that needs time, continuous practice and feedback, that is, it needs to be built. It cannot be considered uniform or something that follows a standard. Each student develops his awareness at different times in different ways, and this can occur inconsistently even in a same student. ${ }^{6-8}$

Given the context, and presenting the theoretical framework adopted, the relevance of the theme is focused on the understanding of the awareness of the world and the self-awareness of the student as a human being. Studies conducted in the field of social knowledge construction are scarce related to the ideas of children on the school reality, as there are few studies that show the perception of students about themselves in the teaching and learning process. ${ }^{9}$

From the perspective adopted, it is believed that these factors are critical for the formation of a student with a critical attitude, who is creative and committed to reality, as recommended by the PPC. As this is a rarely addressed topic, this study aims to understand the self-awareness that an undergraduate nursing student expresses while enrolled in a critical pedagogical proposal.

\section{METHODOLOGY GUIDANCE}

This was a qualitative study based on the educational case study model. ${ }^{10}$ The study participants were 14 students enrolled in the Fundamentals of Professional Nursing Care (FPC) of the Undergraduate Program in Nursing at UFSC.

For the information collection method, we used non-participant observation and interviews. Field observation was conducted from March to July of 2010, as a strategy for approximation with the field and the subjects in the various learning scenarios (small group discussion, lessons in large groups, simulation lab, hospitals). The observation data were recorded in a field diary and then interviews were conducted, recorded and transcribed. The analysis procedure was based on thematic content analysis,$^{10}$ organized in three stages: preanalysis, material exploration, and treatment of results. Information about the research was given to participants that signed the Informed Consent Form, after accepting to participate. Anonymity was guaranteed by the use of speech coding, namely: si (student interview), followed by the order number, and so (observation), followed by serial number. The study was approved by the Ethics Committee of the Federal University of Santa Catarina (protocol 305.209).

\section{RESULTS AND DISCUSSION}

The theme "Being the shadow -awareness of undergraduate nursing students" was organized in three thematic units: "A being deprived of knowledge", "A being who absorbs knowledge," and "A being evaluated by grades."

\section{A being deprived of knowledge}

The self-awareness that students expressed in their reports and that made the construction of this thematic category possible is the recognition of being someone without knowledge, as shown in the following statements: [...] I think you can only be critical if you have knowledge about it, you cannot be critical of something you do not know, something you're not on to [...]. For example, in the independent study class, we have to bring to class, I think [...] like [...] we have to study, we have to seek, yeah, sure, but teachers should deepen the subject [...]. It is you who know it better than me (si12).

In addition, students understand that such knowledge can only be achieved by in-depth study with the professor, and when they do not receive this knowledge from the professor, they feel discouraged to keep up with the study [...] at the beginning of the course I came with a bigger excitement [...] I think a lot was missing when it comes to the class itself. [...] It is not conducted in a way that you remember what you read, it is [...] a dialogued-class, and this dialogue turns out to be very superficial. It is on the surface of everything that you read. It does not delve into the details, you know? [...] It is the details that should be deepened. What you read, it turned out to be insufficient. [...] It is as if you needed someone, who showed up and told you, you know, something to complement what you read [...] when he starts talking about a subject that you have read previously, you remember what you read. [...] The thing is I have to be certain of what I read. [...] to know if it is important in that moment or not (si10).

It was also possible to observe these thoughts through their attitudes in the classroom: the professor [...] gives examples of the second phase of the pain. He asks for some volunteer to read the slide, 'who can read it to me and comment about it'? [silence]. The students are apprehensive, and a student begins to read, but it does not manifest itself. She was quiet. (so1). 
As one can observe, the student ea12 defines himself as unable, insecure and without the abilities to be critical. It includes study as the cursory reading and the act of bringing what he studied to the class as a task to be completed, which will be requested by the teacher. He does not realize that being critical is also demanded during the search for knowledge, while he is reading. The student ea10 stated in his report that even with studying, he understands that the professor is the one who must deepen the knowledge. This awareness was built by his world, which placed him in the condition of being a shadow. Being a shadow is an introjected condition and it is maintained in the students by the oppressors. The purpose of this condition was to make them reproduce the models and fear its transgression, i.e. freedom. For students to be free, they need to expel the shadow and fill that space with other content: the act of exercising autonomy. ${ }^{11}$ This overwhelmed/passive/alienated student does not perceive him/herself as such, therefore he/ she has a naive consciousness. $\mathrm{He} /$ she perceived him/herself as someone who has no knowledge or whose knowledge is insufficient and therefore, he/ she is someone who cannot be critical. This critical condition requires knowledge to be transmitted by the professor. Only then they can discuss in class, and so, they wait.

The awareness brought by the student to the subject is a result of historical influences of a traditional education that considers the student as one who obeys the professor, who is the knowledge holder. ${ }^{12}$ Therefore, he is a receptive, passive subject, with no unique characteristics, who attends classes and responds with answers that the teacher wants to hear. The student is then evaluated using a standardized model, which is applied to all of them. ${ }^{12}$ This attitude of students is also revealed by nursing teachers, participants of a study in Spanish universities. It was found that teachers understand the student as someone who knows nothing, who only learns from the teacher, the one who gives them all the knowledge. ${ }^{13}$

In this context, when challenged to search for new knowledge in activities such as the independent study proposed by the FPC subject, which allows the student to pursue what calls his/her attention without limitation or pre-established texts, questionnaires, and with no previous content given by the teacher, the student does not understand that he/she is free to choose, and expects the teacher to bring the knowledge during the lecture.
So the student experiences difficulty in becoming a critical reader of the world, ${ }^{14}$ as the body of knowledge mechanically assimilated throughout his/her life ends up being nonapplicable in a more complex context and in a reality that is constantly changing. In this sense, the student demonstrates that he was stuck between idealized knowledge and the real demands of learning situations. ${ }^{13}$ As shown by the reports, the student has difficulty understanding in a learning experience, which is one possibility for development of the critical reader. The need to receive confirmation of knowledge by the teacher is part of the student's life, as well as the perception that his knowledge is insufficient and, therefore, that they cannot be the protagonist of their learning process, instead being a simple passive receiver, the shadow of the teacher.

\section{A being who absorbs knowledge}

By perceiving themselves as someone who does not have knowledge, the undergraduate also perceives himself/herself as one that absorbs content and perform duties. The act of studying is an obligation to be completed, and not something designed for the purpose of its development as a human being. We can see this in the following statements from the reports of teaching-learning experiences at earlier stages: [...] What I remember about the second phase is that [...] was not much we could absorb (si12); [...] I had more to study and thus to memorize for exams and then I finished the tests and [...] kind of already put that aside [...] I have forgotten the matter (si23); during the first year I got low scores in math and was reproved by three tenths, with physics it was by five tenths, and it was purely because [...] I did not get the matter right (si1); [...] the professor enters the room and talks a blue streak of all those things to you (si18).

In this statement it is possible to identify the solidified presence of traditional education. The learning process takes place by a variety of content that must be absorbed, in other words, it is external to the student. This expectation is justified by the history of traditional formal education which has, as a principle, teaching the student to learn, in order to receive the knowledge that is going to be reproduced without participating in its construction. Traditional teaching only values memorizing questions whose answer is already known and established. ${ }^{13}$ This means that the student only has the role of absorbing content and his/her opinion, beliefs, and values about what is studied are not taken into account. In the other hand, the student 
obeys rules and follows social stereotypes and expectations - which end up creating barriers to the expression of creativity. ${ }^{14}$

The belief in this process has been taught and is still reproduced and perceived by the student. Through the naive consciousness, students that attend the FPC discipline indicate a dislike to the teaching proposal and justify it by stating that they would prefer the subject to be "like other disciplines," in which the teaching method is still the traditional one: [...] it was my great shock, I was very surprised, just after we concluded the subject of Nursing Fundamentals [...] (si2); [...] At the beginning I had some [...] difficulty (si7); [...] Everyone also had a very big blow for us because this methodology [...] it was very difficult, because we went from a methodology of professor in the front explaining all of it to one that you have to research everything by yourself (si18).

This way of thinking by the student could be observed at times in the class: during the whole dynamic of the explanation of the subject, the class remained quiet and watching. However, some students were disengaged, almost all with their backpacks, briefcases or pockets on their legs and even, in some cases, still on their shoulders, twirling their hair, chatting with each other [...] (so1).

Thus, this ancient and powerful tradition of knowledge transfer is difficult to overcome. ${ }^{7} \mathrm{Al}-$ though there are initiatives to change the teaching and learning proposals as a way to achieve a development of students as creative and autonomous beings, there are still remnants of traditional teaching that hinder and even inhibit the development and expression of creativity and autonomy. The emphasis on the reproduction of knowledge, the memorization of content, the appointment of only one correct answer to a problem, and especially the minimal emphasis on imagination are some examples. ${ }^{16}$

When faced with the teaching proposal of the subject in which the professor facilitates a learning process that the student must build, by himself/ herself, the individual reacts with dissatisfaction, surprise and fear as there is an expectation of the professor as the transmitter of knowledge. Learning is also an obligation, not a choice. The student was always "forced", constrained to study and thus he/she sees study as something mandatory, without the possibility of thinking about the reasons and possibilities of what to study. Beginning in childhood, one is conditioned to participate in the school environment with the predetermined purpose of "studying".

\section{A being evaluated by grades}

In the student's school career, his/her performance in the classroom has always been evaluated by assignments, exams and grades. For the educational system, the institution, the professor and the society, being a student meant having the best performance, as measured by the memory capacity and quantified on a range of zero to ten. The rule of the educational system is still present in the students' statements in this study: [...] in her assignments, [...] I was getting desperate, and we pretty much ate the anatomy book. And because of that, my final grade was 5.5 [...] 5.6 specifically. And [...] I remember when I was talking to her and said: professor, you saw that I dedicated my entire semester. And she was like: "no, I will not help you. If you get this grade, you will be failed" and I was devastated (si26); and she always got good grades in pharmacology, she got a nine and a ten took in the last exam, she always had a good grade, while everybody was getting a three and a half, two, four, five (si18).

During the observations in the classroom, it was possible to identify the presence of this same thought expressed in their attitudes: the professor explains the initial dynamics of the class regarding the physical exam. The students were divided into four groups. This initial moment was one of relaxation and involvement. However, students in Group 3 [a7, a5, a2, a1, a18] started drawing, but they were actually speaking about the pharmacology exam. They realized that only half of the class was present and that they missed to study for the test (so17).

The students, in their reports and field observations, demonstrated an awareness that study was an act of obligation and evaluation whose value was quantified by a final grade. So while attending some subjects, they are concerned with this type of "study", even if they have to miss other classes to do so. Such activities, better known as "assignments" and "exams/tests", are used in traditional teaching as a quantitative measure of student knowledge.

A study conducted in order to verify the evaluation models registered in higher education courses of speech therapy in São Paulo reiterated this statement. The study showed that the evaluation strategy most commonly used in these schools was the theoretical test, followed by assignments, whose main objective consisted in the classification of the student in a score between zero and ten. ${ }^{17}$ This reiterates that traditional education is still part of the higher educational context; therefore, 
for some students in the FPC course, "being a good student" means getting the best grades and delivering assignments on their due date. This student can be understood as one who has learned to be a shadow in the traditional teaching process - that, rather than being in the light, it kept the student in the shadows, something that still persists in the current educational system. This model is expressed implicitly or explicitly through strategies for learning assessment, carried out unilaterally and in an authoritarian manner, without considering the background - the main goal is to evaluate their performance and cognitive skills. ${ }^{11,18}$

Despite the fact that the FCP subject has redesigned the teaching and learning process in a context of greater freedom, without the passive transmission of knowledge, students present a conditioning behavior. Thus, they bring learning experiences that reinforce and legitimize the traditional model of education and the role reserved for both professor and student.

In the case studied, the proposed evaluation of the student involves monitoring the learning throughout the semester, and it is not limited to assignments and exams, but to the development of his/her critical thinking skills in the learning process. This monitoring occurs partly through the building of a portfolio. Evaluation by means of the portfolio by the professor differentiates itself from the quantitative evaluation of traditional education, because the learning processes appear in different ways within it, and it allows more flexibility, making a portfolio something impossible to be standardize. ${ }^{19}$ However, even presenting that proposal to the student, he/she still perceives the evaluation process as something punitive, as it will be assessed by the professor who will assign a grade, establishing a form of judgment. For the student, the grade still defines one as a "good or a bad student,"; the what, how and whydo not matter, but rather how much quantitatively one can know: [...] at the beginning we think: what is this portfolio? Is this just for us to [...] waste time writing a lot of stuff that will be read and evaluated by a teacher? (si23).

This attitude of the student against a new assessment proposal can be explained by the historical moments experienced in previous experiences of evaluation. The student's perception determines the assumption that "being a good or bad student" means, equivalently, having good or bad scores. The only thing that matters is the knowledge required by the assessments applied by the professor, not what the student did to be prepared. In a study conducted with students and professors on the evaluation of the difficulties in the teaching and learning process in a pharmacy course, it was observed that $85 \%$ of students and professors understand the school evaluation as a way to measure the student's knowledge, and that this instrument is equivalent to an "exam". Students perceived the evaluation process as verification of their ability to "retain" content at a specific time. As a method used to measure the amount of absorbed content, the test is translated as an act of learning verification, as a measurement of the student's knowledge. ${ }^{19}$ The present study reinforces the fact that students present a common awareness, in this case the awareness characteristic to the university and to the evaluation process, as a way to measure the knowledge taught by the professor and absorbed by the student, reaffirming that the traditional model of education is still present in the minds of students, as well as among professors. For these individuals, "people just study if they have a test to take, people just study what they expect to be on the test." $18: 38$

In order to break this pattern, it is necessary for students and professors to allow living experiences to overcome passivity and certainties, awakening an epistemological awareness. This awareness is natural to man when he is not oppressed. Without oppression, a man can exercise his freedom and, from there, his creative ability, so he is able to relearn how to learn and to re-read the world. Despite the current situation, it can be said that change is possible, that one can find ingenuity and reach an epistemological awareness. The student is able to evolve a naive curiosity to criticism and to epistemological knowledge, from the moment one discovers himself in the shadows of the dominant ideology. In this transcendent status, we can learn to break free because of the perception of imprisonment and conditioning. From there, one can think about becoming someone new. ${ }^{6,20-22}$

It is important to rethink hegemonic and homogenized knowledge, socialized in the tradition of a field of knowledge in a certain time and historical space, moving the certainties that, without a continuous reflection, end up as absolute truths. Chains of thought and convictions need to be questioned, denouncing the ephemerality of sciences and of the accumulated knowledge (as well as those currently being produced), along with 
attempts of the homogenization of human senses and the meanings of this knowledge in societies. ${ }^{23,24}$

This act of rethinking must also occur parallel to the construction and reconstruction of the political-pedagogical projects of undergraduate courses. Even with the 2001 National Curriculum Guidelines (DCN), few courses have accepted the challenge of changing paradigms and assume critical-creative training. A decade has passed since the publication of DCN for health care, and few changes in the proposed curriculum and teaching practice are identified..$^{25}$

The traditional teaching model is still present across different educational levels, thus establishing the prior experience of the student. This increases the difficulty for changing attitudes, although it is not synonymous with impossibility. The development of an educational proposal that allows the student experience in the world is necessary to create a new formal education experience, assuming the leadership role in their own process of construction as a human, on how to be conscious. The understanding that the student has of self-awareness, and the awareness of the world, is a way to promote changes required in the training process.

The challenge, therefore, is the transformation of the teaching and learning environment in a space of criticism and creativity, so that professors and students deconstruct perceptions of teaching and learning, to build new possibilities. This deconstruction takes place from the moment in which the professor and student develop an awareness about the need to build new ideas and, with this perception, adopt new attitudes.

\section{FINAL CONSIDERATION}

The thematic categories developed in this study were able to reveal that students enrolled in the "Fundamentals for professional care" subject demonstrate a naive and oppressed awareness, conditioned to the observance of rules and standards of what is considered a good and/or a bad student - even when attending a course that allows him to exercise autonomy and self-regulation in the learning process. Thus, they act as beings deprived of knowledge, who are ranked by grades and passively absorb matter. $\mathrm{He} /$ she is in college to learn and to know, but learning, for him/her, at this early stage of the undergraduate program, consists of the obligation to study and reproduce the knowledge transmitted without self-awareness about oneself in the world and about the world itself - and he is, for this reason, alienated.

In order to allow students to develop a critical attitude and engender a praxis of action-reflection-action, in accordance with critical and liberating pedagogy, we must also encourage thinking and the development of studies in the field of nursing education that highlight the weaknesses and capabilities of different educational proposals. Such studies may contribute to the construction of pedagogical knowledge regarding the context and the actors that are involved in this process, such as the professor and the student. The comprehension of the student's self-awareness enables the design of new proposals for the teaching-learning process, that may lead students to free themselves from the professor's shadow and assume an autonomous state of being.

\section{REFERENCES}

1. Freire P. Pedagogia do oprimido. 18. ed. Rio de Janeiro: Paz e Terra; 1987.

2. Brasil, Senado Federal. lei n. 11.274 , de 6 de fevereiro de 2006. Altera a redação dos arts. 29, 30, 32 e 87 da Lei n. 9.394, de 20 de dezembro de 1996, que estabelece as diretrizes e bases da educação nacional, dispondo sobre a duração de nove anos para o ensino fundamental, com matrícula obrigatória a partir dos seis anos de idade.

3. Bordenave JD, Pereira AM. Estratégias de ensinoaprendizagem. $4^{\mathrm{a}}$ ed. Petrópolis (RJ): Vozes; 1989.

4. Ausubel DP. Aquisição e retenção de conhecimentos: uma perspectiva cognitiva. Lisboa (PT): Plátano; 2003.

5. Peixoto MAP, Silva MA, Rocha CC. Aprendizagem e metacognição no ensino de metodologia científica. Rev Ensaio. 2010 Jan-Abr; 12(1):11-26.

6. Freire P. Pedagogia da autonomia: saberes necessários à prática educativa. $43^{\mathrm{a}}$ ed. São Paulo (SP): Paz e Terra; 2009.

7. Freire P. Medo e ousadia: o cotidiano do professor. Rio de Janeiro (RJ): paz e terra; 1986.

8. Freire, P. Pedagogia do oprimido, $13^{\mathrm{a}}$ ed. Rio de Janeiro (RJ): Paz e Terra; 2011.

9. Saravali EG, Guimarães T. Ambientes educativos e conhecimento social: um estudo sobre as representações de escola. Edu Rev. 2010 Abr; 26(01):157-84.

10. Ludke M, Marli EDA. Pesquisa em educação: abordagens qualitativas. São Paulo (SP): EPU, 1986.

11. Minayo MCS. O desafio do conhecimento: pesquisa qualitativa em saúde. $12^{a}$ ed. São Paulo (SP): HUCITEC; 2010. 
12. Freire P. Educação como prática da liberdade. $34^{\text {a }}$ ed. Rio de Janeiro (RJ): Paz e Terra; 2011.

13. Moya JLM, Prado ML. El curriculum de enfermería como prototipo de tejné: racionalidad instrumental y tecnológica. Texto Contexto Enferm. 2009; 18(4):61726.

14. Souza KSM. O sujeito da educação superior: subjetividade e cultura. Psicol Estud. 2009 Jan-Mar; 14(1):129-35.

15. Freire P. Pedagogia do oprimido. $50^{\mathrm{a}}$ ed. Rio de Janeiro (RJ): Paz e Terra; 2011.

16. Wechsler SM. Criatividade na cultura brasileira: uma década de estudos. Psicol Teor Investig Prát. 2001; (6):215-27.

17. Nakano TC, Santos E, Zavariz SF, Wechsler SM, Martins E. Estilos de pensar e criar em universitários das áreas de humanas e sociais aplicadas: diferenças por gênero e curso. Psicol Teor Prát. 2010 Mar; 12(3):120-34.

18. Alencar EMLS, Fleith DS. Criatividade: múltiplas perspectivas. $3^{\mathrm{a}}$ ed. Brasília (DF): EdUnB; 2003.

19. Nascimento EM, Paschoal SRG. Estratégias de avaliação do aluno: uma análise de programas de ensino de cursos de fonoaudiologia. Distúrb Comum. 2008 Dez; 20(3):349-54.

20. Moretto VP. Prova: um momento privilegiado de estudo, não um acerto de contas. $9^{\mathrm{a}} \mathrm{ed}$. Rio de janeiro (RJ): Lamparina; 2010.

21. Freire P. Professora sim, tia não: cartas a quem ousa. $23^{a}$ ed. São Paulo (SP): Civilização Brasileira; 2012.

22. Freire P. Conscientização: teoria e prática da libertação: uma introdução ao pensamento de Paulo Freire [tradução de Kátia de Mello e silva; revisão técnica de Benedito Eliseu Leite Cintra]. São Paulo (SP): Cortez \& Moraes, 1979.

23. Bagnato MHS, Monteiro MI. Perspectivas interdisciplinar e rizomática na formação dos profissionais da saúde. Trab Educ Saúde. 2006; 4(2):247-58.

24. Moya JLM, Backes VMS, Prado ML, Sandin MP. La enfermería como grupo oprimido: las voces de las protagonistas. Texto contexto Enferm. 2010 Out-Dez; 19(4):609-17.

25. Silva MG, Fernandes JD, Teixeira GAS, Silva RMO. Processo de formação da(o) enfermeira(o) na contemporaneidade: desafios e perspectivas. Texto Contexto Enferm. 2010; 19(1):176-84. 